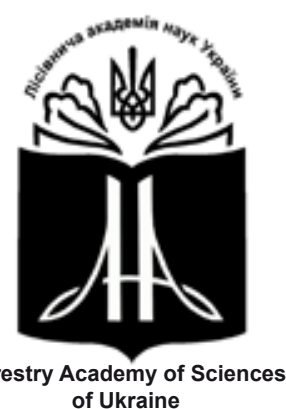

Forestry Academy of Sciences of Ukraine
Наукові праці Лісівничої академії наук України Proceedings of the Forestry Academy of Sciences of Ukraine http://fasu.nltu.edu.ua https://doi.org/10.15421/411818

Article received 2018.06.08

Article accepted 2018.10.25
ISSN 1991-606X print

ISSN 2616-5015 online

@ $\triangle$ Correspondence author

Volodymyr Zaika

vkzaika@ukr.net
General Chuprynka st., 103, Lviv, 79057, Ukraine

УДК $630 * 232$

\title{
Ріст і формування дубових деревостанів за участю липи дрібнолистої в умовах свіжої грабової діброви Західного Поділля
}

\author{
В. К. Заїка', Ю. С. Каленюк²
}

\begin{abstract}
Досліджено лісівничо-таксаџійні показники та санітарний стан дубових деревостанів різного віку за участю у їх складі липи дрібнолистої. Встановлено, щь тут формуються складні деревостани за участю дуба звичайного, ясена звичайного, граба звичайного, липи дрібнолистої, в'яза голого, кленів гостролистого і явора та інших деревних видів. Частка липи у їх складі становить від поодиноких дерев до 6-8 одинищь. Серед них переважають деревостани, в яких частка липи становить 2-4 одиниці. Дуб звичайний росте за II-I $I^{b}$ бонітетом та досягає максимальної продуктивності (I ${ }^{a}-I^{b}$ бонітет) у деревостанах, де частка липи у складі змінюється в межах 2-8 одиниць і відстає в рості від дуба за висотою на 10,0-46,1\%. Найгіршим ростом дуб звичайний характеризується в деревостанах, де відмінності за висотою між ним і липою становлять до $7 \%$.

Повнота деревостанів $і$ запас стовбурової деревини відзначаються високою варіабельністю навіть у межах вікових груп. У середньовікових деревостанах абсолютна повнота становить 21,4-34,0 $\mathrm{M}^{2} / 2 \mathrm{a}$, а запас деревини - 172-374 $\mathrm{M}^{3} / 2 a$. У пристигаючих деревостанах иі показники, відповідно, становлять 24,6-34,9 $\mathrm{M}^{2} / 2$ а $i$

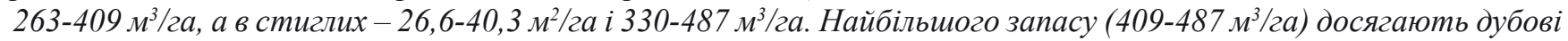
деревостани, де частка липи у їх складі становить 3-6 одиниці. Водяні пагони у дерев дуба не виявлено на 20\% дослідних ділянок. В інших деревостанах різної повноти і продуктивності кількість дерев дуба з водяними пагонами становить 5,3-53,3\%. У деревостанах переважсають дерева I і II категорій санітарного стану. Сухі дерева трапляються на 70\% дослідних ділянок в кількості 1,2-7,2\%. Індекс санітарного стану дуба змінюється в межах 1,36-2,65.
\end{abstract}

Ключові слова: свіжа грабова діброва; дубові деревостани; липа дрібнолиста; санітарний стан; ріст; формування деревостанів; лісівничо-таксаційні показники; супутні деревні види; водяні пагони.

Вступ. Одним із напрямків формування високопродуктивних і біологічно стійких деревостанів $\epsilon$ введення підгінних видів, які б характеризувались оптимальною сумісністю 3 головними деревними породами на фітоценотичному, алелопатичному та інших рівнях. На Поділлі поширені такі підгінні породи, як липа дрібнолиста, клен гостролистий i граб звичайний. Вивченню ролі підгінних деревних порід у підвищенні продуктивності лісостанів із дуба звичайного (Quercus robur L.) у Лісостеповій зоні особливу увагу приділяли багато дослідників (Gordienko, 1973, Gordienko \& Karpenko, 1996, Gordienko I. \& Gordienko N., 2005). Однак дослідженню ролі липи дрібнолистої (Tilia cordata Mill.) у формуванні дубових деревостанів останнім часом приділяють мало уваги. Це питання для умов Західного Лісостепу залишається актуальним.

До родини липових входить до сорока родів, які об'єднують близько 500 видів, поширених на різних континентах, але здебільшого у тропічних кра-

Заїка Володимир Костянтинович - академік Лісівничої академії наук України, доктор біологічних наук, професор кафедри лісівництва. Національний лісотехнічний університет України, вул. генерала Чупринки, 103, м. Львів, 79057, Україна. Тел.: 032-239-27-85, +38-067148-06-26. E-mail: vkzaika@ukr.net

2 Каленюк Юрій Степанович - викладач, Кременецькиий лісотехнічний коледж, вул. Молодіжна 1, с. Білокриниця Тернопільської обл., 47014, Україна. Тел.: 035-46-52-404; +38-096-367-15-16. E-mail: kaleniukyurii@gmail.com 
їнах Південно-Східної Азії, Африки і в Бразилії. У помірному кліматі Північної півкулі трапляється близько 45 видів лип (Murakhtanov, 1981).

Липа дрібнолиста має широкий ареал. Вона успішно росте в умовах Степу і Лісостепу, в зоні хвойно-широколистяних лісів, частково в тайговій зоні (південна і середня тайга). У Сибіру вона трапляється островами майже до Іртиша. Рідко липа дрібнолиста трапляється також у Криму і на Кавказі, піднімаючись в гори до 1800 м над рівнем моря. На Далекому Сході липа дрібнолиста замінюється манджурською та амурською (Murakhtanov, 1981).

В Україні сходяться ареали трьох видів лип: дрібнолистої, широколистої і сріблястої (Murakhtanov, 1981). Найпоширеніша тут липа дрібнолиста. У ліcax України вона трапляється майже у всіх типах лісу Лісостепової і Степової зон та на Поліссі. Найбільше липових деревостанів росте в Лісостеповій зоні (70\%) і меншою мірою на Поліссі (20\%) (Gensyruk, Shchevchenko, Bondar, et al., 1981). Найбільше деревостанів за участю липи дрібнолистої зосереджено в північно-східній і центральній частинах України (Soshensky, Girs \& Swynchuk, 2015).

Липа дрібнолиста успішно росте в дібровах і судібровах, де іï частка в деревостанах може досягати до 3-4 одиниць і більше. Однак переважають деревостани $(80 \%)$ з часткою липи у їх складі 1 -2 одиниці (Soshensky, Girs \& Swynchuk, 2015). Встановлено, що на площі $77 \%$ липа має природне походження, 3 яких $58 \%$ належить до порослевого і $19 \%$ - до насінного. Штучні липові насадження ростуть на площі 23\% (Soshensky, Girs \& Swynchuk, 2015). Вікова структура липових деревостанів характеризується певною нерівномірністю. В Україні переважають середньовікові $(45,3 \%)$ і стиглі $(27,4 \%)$ деревостани. Пристиглі і перестійні деревостани займають площу, відповідно, 13,6 і 12,0\%, а молодняки - менше 2\% (Soshensky, Girs \& Swynchuk, 2015). Останнім часом значну увагу приділяють вивченню таксаційної будови липових деревостанів та будови стовбурів іiї дерев (Swynchuk. \& Soshensky, 2014, Soshensky, 2015, Soshensky, 2015, Soshensky, 2016).

У сприятливих умовах висота дерев липи досягає 22-27 м, а діаметр - 25-40 см. Тривалість іiі онтогенезу становить понад 100 років і залежить від умов та розташування у фітоценозі (Murakhtanov, 1981).

Липа дрібнолиста відіграє важливе лісівниче й екологічне значення в лісових фітоценозах. У листках T. cordata міститься 14 елементів: 4 макро- $(\mathrm{K}$, $\mathrm{Na}, \mathrm{Ca}, \mathrm{Mg}$ ) і 10 мікроелементів ( $\mathrm{Fe}, \mathrm{Zn}, \mathrm{Mn}, \mathrm{Cu}, \mathrm{Ni}$, $\mathrm{Co}, \mathrm{Pb}, \mathrm{Cd}, \mathrm{Ba}, \mathrm{Sr}$ ). Особливо у її листках значною мірою нагромаджується калій, кальцій і магній (Lukanyuk, 2013). Вона зменшує кислотність грунту, збагачує його верхні горизонти кальцієм, вливає на мікрокліматичні умови під наметом деревостанів тощо (Gordienko \& Karpenko, 1996, Platonova, Lantratova \& Golubin, 2006). Липа також сприяє появі нових екологічних ніш для різних видів рослин і збільшенню видового різноманіття в лісових екосистемах (Platonova, Lantratova \& Golubin, 2006).

Незважаючи на встановлені закономірності щодо ролі липи у лісових фітоценозах, слабо вивче- ним є питання іï значення в таких складних типах лісу, як свіжа грабова діброва в Західному Поділлі. Тут у складі супутніх деревних видів домінують граб, клени гостролистий і явір та в'яз, які добре поновлюються на зрубах чи під наметом лісу природним насінним шляхом. Для липи ж характерне порослеве поновлення, надійність якого є слабкою. Водночас аналіз створених лісових культур за останні десятиріччя показує, що штучне лісорозведення липи дрібнолистої у регіоні дослідження практично не проводять. Як наслідок, склалася тенденція до їі випадання зі складу значної кількості деревостанів.

Об'єкти та методика дослідження. Об'єкт дослідження - дубові деревостани різного віку та частки у їх складі липи дрібнолистої в умовах свіжої грабової діброви Західного Поділля. Предмет дослідження - ріст, формування і санітарний стан дуба в деревостанах за участю липи дрібнолистої.

Мета дослідження - встановити влив липи дрібнолистої на ріст і формування деревостанів та санітарний стан дуба звичайного.

Дослідження здійснювали в дубових деревостанах за участю липи дрібнолистої, які формуються в умовах свіжої грабової діброви Західного Поділля. Для дослідження підібрали деревостани різного віку та частки липи у їх складі. Ділянки входять до складу лісового фонду ДП «Кременецьке, Тернопільське і Чортківське лісове господарство». Пробні площі закладали відповідно до чинних вимог (SOU 02.02-37-476:2006, 2006), санітарний стан вивчали за прийнятими настановами (Sanitary rules.., 1995).

Результати дослідження. Свіжа грабова діброва $€$ одним із найпоширеніших типів лісу Західного Поділля, в якому формуються складні багатоярусні дубові деревостани за участю ясена звичайного, клена гостролистого, клена-явора, в'яза голого, осики, граба звичайного тощо. Супутні деревні породи, загалом, сприяють формуванню високопродуктивних і біологічно стійких дубових деревостанів. Важливе лісівничо-екологічне значення в таких деревостанах має липа дрібнолиста (серцелиста). Вона впливає на формування мікроклімату під наметом деревостанів, сприяє перебігу мікробіологічним процесам у лісовій підстилці і грунті та очищенню дерев дуба від сучків.

Результати вивчення лісівничо-таксаційних показників деревостанів за участю липи дрібнолистої наведено в табл. 1.

Дослідження проводили у середньовікових (пр. пл. 1-13), пристиглих (14-17) і стиглих (18-22) деревостанах. Інтегральним показником продуктивності деревостанів є бонітет. У середньовікових деревостанах бонітет дуба змінюється від II до I', у пристиглих - від I до I ${ }^{\mathrm{a}}$ й у стиглих - від II до I. Ріст дуба в таких складних деревостанах свіжої грабової діброви залежить від багатьох чинників i особливо - від взаємовпливу між деревними видами під час формування фітоценозів. Очевидно, що вплив липи на ріст дуба змінюється залежно від іiі 
частки у складі деревостанів. У багатьох роботах відзначено позитивний вплив липи на ріст дуба (Gordienko, 1973, Gordienko \& Karpenko, 1996, Gordienko I. \& Gordienko N., 2005, Polonchuk, 1965, Kharytonovych, 1968, Yurkevych, 1960). На нашу думку, такого однозначного твердження не може бути. Липа, як і будь-який інший вид, характеризується конкурентними властивостями, а тому під час формування деревостанів може проявляти і негативний вплив на ріст дуба та інших деревних видів. Встановлено достатньо вагому тенденцію у взаємодії між дубом і липою у грабових дібровах Західного Поділля. Дуб, незалежно від віку, росте за I ${ }^{\mathrm{a}}-\mathrm{I}^{\mathrm{b}}$ бонітетом у деревостанах (пр. пл. 2, 3, 5, 7, 11, 15, 16, 21), де частка липи у їх складі змінюється переважно в межах 2-8 одиниць і відстає в рості від дуба за висотою на 10,0-46,1\%. Кількість дерев липи в цих деревостанах становить 36-800 екз./га.

Табличяя 1

Лісівничо-таксаційні показники дубових деревостанів за участю липи дрібнолистої в умовах свіжої грабової діброви Західного Поділля

\begin{tabular}{|c|c|c|c|c|c|c|c|c|}
\hline \multirow{2}{*}{$\begin{array}{l}\text { № } \\
\text { пр. } \\
\text { пл. }\end{array}$} & \multirow{2}{*}{ Склад деревостану } & \multirow{2}{*}{$\begin{array}{l}\text { Вік, } \\
\text { років }\end{array}$} & \multirow{2}{*}{$\begin{array}{c}\text { Індекс } \\
\text { деревного } \\
\text { виду }\end{array}$} & \multicolumn{2}{|c|}{ Середні } & \multirow[b]{2}{*}{ Бонітет } & \multirow{2}{*}{$\begin{array}{l}\text { Повнота, } \\
\text { м²/га }^{2}\end{array}$} & \multirow{2}{*}{$\begin{array}{l}\text { Запас, } \\
\mathbf{m}^{3} / г а\end{array}$} \\
\hline & & & & $\mathrm{d}, \mathrm{cm}$ & $\mathrm{h}, \mathrm{M}$ & & & \\
\hline 1 & 10Лпд + Бп & 45 & Лпд & 16,9 & 17,1 & I & 32,3 & 302 \\
\hline 2 & 8Лпд1Мдє1Гз + Дз, Клг, Чш & 51 & $\begin{array}{l}\text { Лпд } \\
\text { Дз }\end{array}$ & $\begin{array}{l}20,3 \\
34,0\end{array}$ & $\begin{array}{l}19,3 \\
25,4\end{array}$ & $\begin{array}{l}\mathrm{I} \\
\mathrm{I}^{\mathrm{b}}\end{array}$ & 34,0 & 351 \\
\hline 3 & 6Лпд2Ясз1 Дз1Бп + Гз, Взг, Клг & 45 & $\begin{array}{l}\text { Лпд } \\
\text { Дз }\end{array}$ & $\begin{array}{l}18,4 \\
19,0\end{array}$ & $\begin{array}{l}16,4 \\
19,1\end{array}$ & $\begin{array}{c}\mathrm{I} \\
\mathrm{I}^{\mathrm{a}}\end{array}$ & 22,0 & 203 \\
\hline 4 & 4Лпд2Ясз2Чш1Дз1Клг + Дч, Гз & 55 & $\begin{array}{l}\text { Лпд } \\
\text { Дз }\end{array}$ & $\begin{array}{l}21,9 \\
24,0\end{array}$ & $\begin{array}{l}20,4 \\
21,5\end{array}$ & $\begin{array}{l}\text { I } \\
\text { I }\end{array}$ & 31,7 & 374 \\
\hline 5 & 4Дз3Клг2Лпд1Бп + Гз, Кля, Взг & 50 & $\begin{array}{l}\text { Дз } \\
\text { Лпд }\end{array}$ & $\begin{array}{l}26,4 \\
16,3\end{array}$ & $\begin{array}{l}20,6 \\
16,6\end{array}$ & $\begin{array}{l}\mathrm{I}^{\mathrm{a}} \\
\mathrm{II}\end{array}$ & 24,6 & 262 \\
\hline 6 & 5Лпд3Дз2Гз + Кля & 56 & $\begin{array}{l}\text { Дз } \\
\text { Лпд }\end{array}$ & $\begin{array}{l}21,4 \\
20,1\end{array}$ & $\begin{array}{l}19,5 \\
18,1\end{array}$ & $\begin{array}{l}\text { I } \\
\text { II }\end{array}$ & 26,0 & 255 \\
\hline 7 & 4Лпд3Дз2Гз1Чш & 56 & $\begin{array}{l}\text { Дз } \\
\text { Лпд }\end{array}$ & $\begin{array}{l}39,1 \\
25,1\end{array}$ & $\begin{array}{l}25,6 \\
21,9\end{array}$ & $\begin{array}{l}\mathrm{I}^{\mathrm{b}} \\
\mathrm{I}^{\mathrm{a}}\end{array}$ & 23,7 & 262 \\
\hline 8 & 5Дз4Лпд1Гз + Ясз, Клг, Чш & 55 & $\begin{array}{l}\text { Дз } \\
\text { Лпд }\end{array}$ & $\begin{array}{l}20,5 \\
18,3\end{array}$ & $\begin{array}{l}18,4 \\
17,4\end{array}$ & $\begin{array}{l}\text { II } \\
\text { II }\end{array}$ & 28,7 & 271 \\
\hline 9 & 5Дз4Лпд1Гз & 58 & $\begin{array}{l}\text { Дз } \\
\text { Лпд }\end{array}$ & $\begin{array}{l}22,7 \\
22,1\end{array}$ & $\begin{array}{l}19,0 \\
20,3\end{array}$ & $\begin{array}{c}\text { II } \\
\text { I }\end{array}$ & 31,7 & 323 \\
\hline 10 & 5Дз3Лпд1Кля1Гз + Ясз & 41 & $\begin{array}{l}\text { Дз } \\
\text { Лпд }\end{array}$ & $\begin{array}{l}18,9 \\
10,1\end{array}$ & $\begin{array}{l}17,0 \\
12,2\end{array}$ & I & 22,8 & 196 \\
\hline 11 & 3Дз4Гз2Лпд1Ясз + Клг, Чш & 59 & $\begin{array}{l}\text { Дз } \\
\text { Лпд }\end{array}$ & $\begin{array}{l}26,8 \\
20,3\end{array}$ & $\begin{array}{l}23,0 \\
20,7\end{array}$ & $\begin{array}{l}\mathrm{I}^{\mathrm{a}} \\
\mathrm{I}\end{array}$ & 31,2 & 345 \\
\hline 12 & 10Дз + Бп & 44 & Дз & 15,9 & 16,1 & II & 21,4 & 172 \\
\hline 13 & 9Дз1Ос + Лпд, Гз, Чш & 55 & $\begin{array}{l}\text { Дз } \\
\text { Лпд }\end{array}$ & $\begin{array}{l}20,8 \\
11,3\end{array}$ & $\begin{array}{l}18,2 \\
12,3\end{array}$ & II & 22,3 & 214 \\
\hline 14 & 5Дз2Лпд1Клг1Гз1Взг + Бп, Чш & 63 & $\begin{array}{l}\text { Дз } \\
\text { Лпд }\end{array}$ & $\begin{array}{l}26,2 \\
16,1\end{array}$ & $\begin{array}{l}23,8 \\
17,5\end{array}$ & I & 29,7 & 325 \\
\hline 15 & 6Дз3Лпд1Гз + Oc & 75 & $\begin{array}{l}\text { Дз } \\
\text { Лпд }\end{array}$ & $\begin{array}{l}32,6 \\
28,3\end{array}$ & $\begin{array}{l}29,1 \\
24,8\end{array}$ & $\begin{array}{l}\mathrm{I}^{\mathrm{a}} \\
\mathrm{I}\end{array}$ & 31,2 & 409 \\
\hline 16 & 9Дз1Гз + Лпд, Клг, Взг & 64 & $\begin{array}{l}\text { Дз } \\
\text { Лпд }\end{array}$ & $\begin{array}{l}27,4 \\
10,8\end{array}$ & $\begin{array}{l}23,0 \\
12,4\end{array}$ & $\mathrm{I}^{\mathrm{a}}$ & 24,6 & 263 \\
\hline 17 & 6 бГз2Лпд1Клг $\frac{10 Д 3}{1 Ч}+$ Кля, Бкл, Взг $^{*}$ & $\frac{77}{-}$ & $\begin{array}{c}\text { Дз } \\
\text { Лпд }\end{array}$ & $\frac{27,0}{10,8}$ & $\frac{23,4}{13,9}$ & $\frac{\mathrm{I}}{-}$ & $\frac{26,6}{9,3}$ & $\frac{310}{70}$ \\
\hline 18 & 6Лпд2Дз2Гз & 100 & $\begin{array}{c}\text { Дз } \\
\text { Лпд }\end{array}$ & $\begin{array}{l}45,1 \\
40,7\end{array}$ & $\begin{array}{l}27,3 \\
26,3\end{array}$ & $\begin{array}{l}\text { I } \\
\text { II }\end{array}$ & 34,3 & 428 \\
\hline 19 & 5Дз3Лпд2Гз + Клг & 90 & $\begin{array}{c}\text { Дз } \\
\text { Лпд }\end{array}$ & $\begin{array}{l}35,8 \\
31,5\end{array}$ & $\begin{array}{l}25,8 \\
24,4\end{array}$ & $\begin{array}{l}\text { I } \\
\text { II }\end{array}$ & 40,3 & 487 \\
\hline 20 & 2Дз5Гз2Лпд1Ясз + Клг, Взг & 92 & $\begin{array}{l}\text { Дз } \\
\text { Лпд }\end{array}$ & $\begin{array}{l}28,8 \\
39,5\end{array}$ & $\begin{array}{l}25,1 \\
25,0\end{array}$ & $\begin{array}{l}\text { II } \\
\text { II }\end{array}$ & 28,3 & 330 \\
\hline 21 & 5Дз3Гз2Лпд & 96 & $\begin{array}{l}\text { Дз } \\
\text { Лпд }\end{array}$ & $\begin{array}{l}48,8 \\
35,3\end{array}$ & $\begin{array}{l}30,7 \\
26,5\end{array}$ & $\mathrm{I}^{\mathrm{a}}$ & 26,6 & 342 \\
\hline 22 & 9Дз1Гз + Лпд, Ясз & 89 & $\begin{array}{c}\text { Дз } \\
\text { Лпд }\end{array}$ & $\begin{array}{l}34,9 \\
22,4 \\
\end{array}$ & $\begin{array}{l}27,6 \\
23,3 \\
\end{array}$ & $\begin{array}{l}\text { I } \\
\text { II }\end{array}$ & 30,9 & 395 \\
\hline
\end{tabular}

Примітки: Дз - дуб звичайний, Лпд - липа дрібнолиста, Клг - клен гостролистий, Кля - клен-явір, Бкл - бук лісовий, Гз - граб звичайний, Чш - черешня, Ясз - ясен звичайний, Взг - в’яз голий, Мдє - модрина європейська, Бп - береза повисла, Ос - осика, Дч - дуб червоний.

* У чисельнику - перший ярус, у знаменнику - другий. 
За I класом бонітету дуб росте в деревостанах (пр. пл. 4, 6, 10, 14, 17, 18, 19, 22), де частка липи змінюється від поодиноких дерев і до 5-6 одиниць у їх складі. Кількість дерев липи у цих деревостанах змінюється в межах 60-786 екз./га, а відставання іiї в рості від дуба за висотою становить $3,7-40,6 \%$. Найгіршим ростом дуб характеризується на ділянках $8,9,13,20$, де він досягає II класу бонітету. Відмінності у рості за висотою дуба і липи в цих деревостанах є найменшими i становлять 0,4-6,8 \%. При цьому на ділянці 9 липа за висотою перевищує дуба. Частка липи у складі цих деревостанів становить 2-4 одиниці, а кількість іiі дерев - 152-428 екз./га. Треба відзначити ділянку 13, де липа істотно відстає від дуба за висотою і діаметром. Очевидно, це значно молодше покоління, яке зазвичай має порослеве походження. За кількості дерев 300 екз./га частка липи тут становить лише декілька відсотків. Аналогічними також є деревостани на ділянках 16, 17 і 22. У цих деревостанах абсолютно домінує дуб, де його часка становить 9-10 одиниць. У таких деревостанах ріст дуба звичайного визначається конкурентною внутрівидовою взаємодією, а вплив липи й інших деревних видів $\epsilon$ мінімальним.

Встановлено залежності впливу представництва липи серцелистої в деревостанах на ріст дуба звичайного. Коефіцієнт кореляції між висотою липи і дуба становить 0,86 і описується поліномним рівнянням (рис., а). Зі збільшенням висоти липи висота дубової частини деревостану, зазвичай, зростає. Виділяються із загальної закономірності деревостани на ділянках 8, 9 і 16, 17. У деревостанах на пробних площах 8 i 9 липа пригнічує ріст дуба, а на 16 і 17 встановлено дуже велике відставання росту липи від росту дуба.

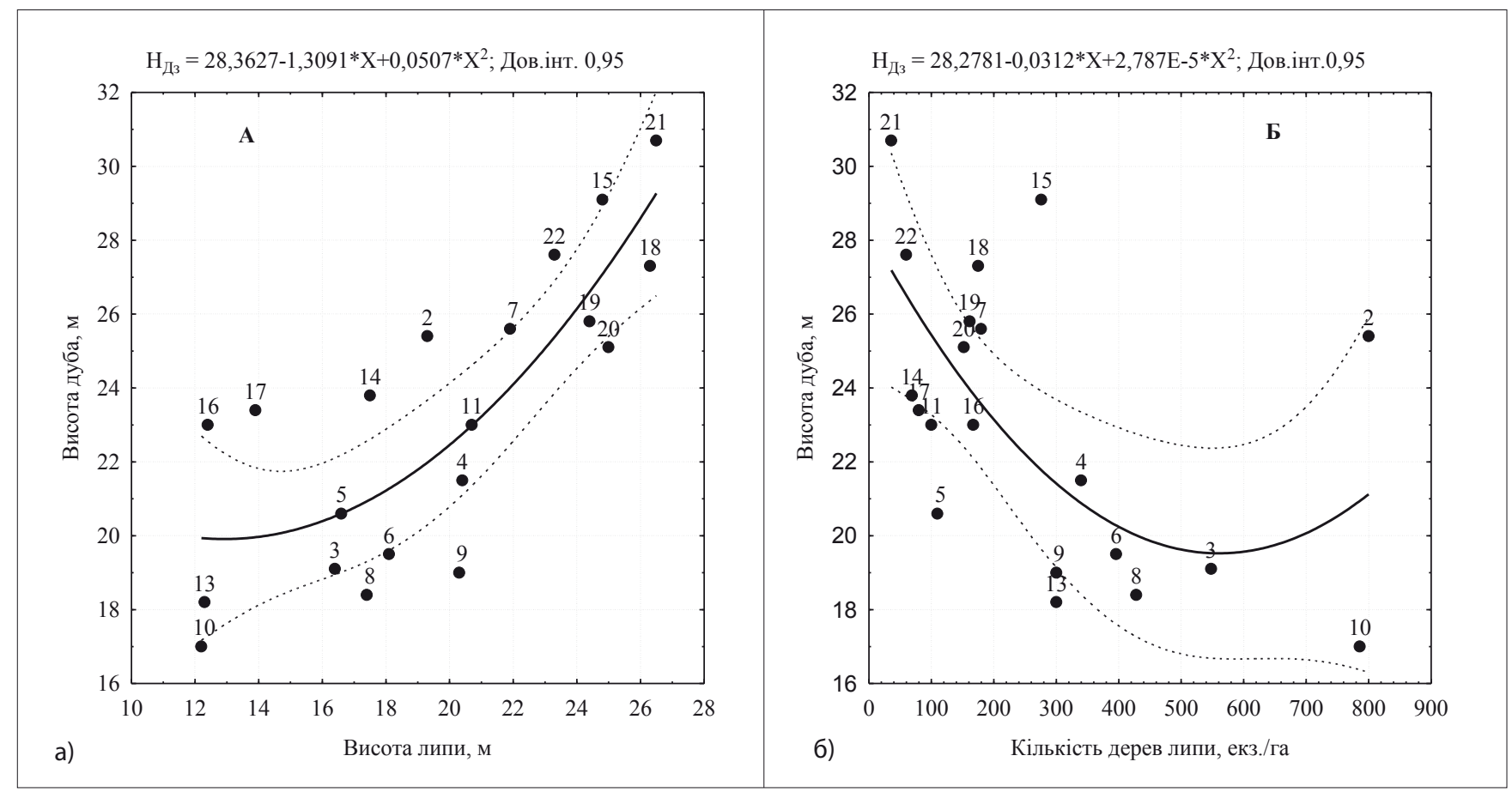

Рис. Зв’язок між висотами дуба та липи (а) і кількістю їі дерев (б)

Кореляційний зв'язок між кількістю дерев липи в деревостанах і середньою висотою дуба виявився зворотним $(\mathrm{r}=-0,49)$ та описується поліномною залежністю (рис., б). 3 неї видно, що зі збільшенням кількості дерев липи в деревостанах висота дуба звичайного знижується і особливо у проміжку від 100 до 200 екз./га. Однак існують і відхилення від встановленої загальної закономірності. Так, на ділянці 15 кількість дерев липи становить 276 екз./га, а дуб росте за I ${ }^{a}$ класом бонітету. Водночас у деревостані на пр. пл. 13 за густоти липи 300 екз./га дуб росте за II класом бонітету. У деревостанах на ділянках 2 і 10 ріст дуба характеризується I-I класами бонітету. У цих деревостанах кількість дерев дуба становить близько 800 на гектарі. Позитивний вплив липи на ріст дуба тут зумовлений значним на 24-28\% - iї відставанням за висотою від дуба.
Отже, липа стимулює ріст дуба за висотою і за значної її густоти, але за умови значного відставання в рості від дуба.

Здійснені дослідження показали, що в умовах Західного Поділля сформувались деревостани з різною повнотою і запасом деревини. Так, у середньовікових деревостанів абсолютна повнота змінюється в межах 21,4-34,0 м²/га, а запас - 172-374 м³/га (див. табл. 1). Низькою повнотою $\left(21,4-23,7 \mathrm{~m}^{2} /\right.$ га) характеризуються деревостани на ділянках $3,7,10$, 12 і 13. У їх складі липа має різну частку та інтенсивність росту. Інтенсивність росту дуба варіює від II до I ${ }^{\mathrm{a}}$ класу бонітету. Відносно значними повнотами і запасами деревини характеризуються середньовікові деревостани на ділянках 2, 4, 9 i 11. В них абсолютна повнота становить $31,2-34,0 \mathrm{~m}^{2} /$ га і запас деревини 323-374 м³/га. Частка липи у складі цих 
деревостанів коливається в межах 2-8 одиниць, а дуб росте за I-I ${ }^{\mathrm{b}}$ класами продуктивності.

Повнота і запас пристиглих і стиглих деревостанів також варіюють у значних межах. Так, абсолютна повнота пристиглих деревостанів становить 24,6-34,9 м²/га, а запас 263-409 м³/га (див. табл. 1). У стиглих деревостанів ці показники, відповідно, коливаються в межах 26,6-40,3 м²/га і 330-487 м³/га. Частка липи в цих деревостанах варіює від поодиноких дерев до 6 одиниць, проте переважно вона становить 2-3 одиниці. Найбільшого запасу (409487 м $^{3} /$ га) досягають деревостани, де частка липи у їх складі становить 3-6 одиниці.

Статистичні показники дослідних деревостанів наведено в табл. 2.

Унаслідок значної диференціації дерев у деревостанах коефіцієнт варіації діаметрів дерев $є$ значним і змінюється в межах 25,0-77,9 \% (див. табл. 2). На ділянках $5,8,10,14,15,16$ його значення переви- щує $50 \%$. Нормальний розподіл дерев за діаметром спостерігається тільки в деревостані на ділянці 9 $(\mathrm{A}=0,02)$. На всіх інших ділянках розподіл дерев за діаметром характеризується правосторонньою асиметрією. Помірний ступінь косості розподілу дерев виявлено у $40 \%$ деревостанів, а сильний - у $50 \%$. Найбільшою правосторонньою асиметрією характеризуються деревостани на ділянках 10, 16, 20 і 21 (А > 1). За показниками ексцесу диференціація деревостанів виявилась ще більшою, ніж за асиметрією. Він змінюється від -1,212 до 1,874. Незначним ступенем крутості розподілу дерев характеризуються $50 \%$ деревостанів, помірним - $32 \%$ i сильним $-18 \%$.

Отже, для дослідних деревостанів характерна правостороння форма кривої розподілу дерев у деревостанах за діаметром з переважанням помірного i сильного ступеня косості та незначним і помірним ступенями крутості.

Таблиия 2

Статистичні показники деревостанів для середнього діаметра

\begin{tabular}{|c|c|c|c|c|c|c|}
\hline \multirow{2}{*}{ № пр. пл. } & \multirow{2}{*}{ Склад деревостану } & \multirow{2}{*}{ Вік, років } & \multicolumn{4}{|c|}{ Показники } \\
\hline & & & $\mathrm{D}, \mathrm{cm}$ & $\mathrm{V}, \%$ & A & E \\
\hline 1 & 10Лпд + Бп & 45 & $16,0 \pm 0,5$ & 34,3 & 0,495 & 0,313 \\
\hline 2 & 8Лпд1Мдє1Гз + Дз, Клг, Чш & 51 & $18,8 \pm 0,6$ & 37,4 & 0,482 & 0,238 \\
\hline 3 & 6Лпд2Ясз1Дз1Бп + Гз, Взг, Клг & 45 & $17,2 \pm 0,4$ & 36,5 & 0,377 & 0,163 \\
\hline 4 & 4Лпд2Ясз2Чш1Дз1Клг + Дч, Гз & 55 & $24,0 \pm 1,0$ & 38,5 & 0,494 & $-0,125$ \\
\hline 5 & 4Дз3Клг2Лпд1Бп + Гз, Кля, Взг & 50 & $15,3 \pm 0,8$ & 67,4 & 0,985 & 0,381 \\
\hline 6 & 5Лпд3Дз2Гз + Кля & 56 & $16,8 \pm 0,5$ & 44,2 & 0,120 & $-0,778$ \\
\hline 7 & 4Лпд3Дз2Гз1Чш & 56 & $21,0 \pm 0,9$ & 47,7 & 0,798 & 0,226 \\
\hline 8 & 5Дз4Лпд1Гз + Ясз, Клг, Чш & 55 & $14,3 \pm 0,4$ & 55,7 & 0,523 & $-0,435$ \\
\hline 9 & 5Дз4Лпд1Гз & 58 & $17,0 \pm 0,8$ & 48,2 & 0,02 & $-1,076$ \\
\hline 10 & 5Дз3Лпд1Кля 1 Гз + Ясз & 41 & $8,5 \pm 0,4$ & 77,9 & 1,151 & 0,613 \\
\hline 11 & 3Дз4Гз2Лпд1Ясз + Клг, Чш & 59 & $17,0 \pm 0,6$ & 47,8 & 0,871 & 0,181 \\
\hline 12 & 10Дз + Бп & 44 & $15,1 \pm 0,4$ & 35,5 & 0,254 & 0,012 \\
\hline 13 & 9Дз1Ос + Лпд, Гз, Чш & 55 & $17,8 \pm 0,7$ & 44,0 & 0,481 & 0,006 \\
\hline 14 & 5Дз2Лпд1Клг1Гз1Взг + Бп, Чш & 63 & $17,3 \pm 0,6$ & 53,1 & 0,515 & $-0,847$ \\
\hline 15 & 6Дз3Лпд1Гз + Oc & 75 & $21,2 \pm 1,3$ & 58,7 & 0,374 & $-1,212$ \\
\hline 16 & 9Дз1Гз + Лпд, Клг, Взг & 64 & $13,7 \pm 0,6$ & 66,2 & 1,193 & 0,718 \\
\hline 17 & 6 бГз2Лпд1Клгг1Чш + Кля, Бкл, Взг & $\frac{77}{-}$ & $\frac{26,2 \pm 0,8}{8,2 \pm 0,2}$ & $\frac{25,0}{43,1}$ & $\frac{0,612}{0,803}$ & $\frac{-0,602}{0,364}$ \\
\hline 18 & 6Лпд2Дз2Гз & 100 & $30,6 \pm 1,4$ & 44,9 & 0,096 & $-0,922$ \\
\hline 19 & 5Дз3Лпд2Гз + Клг & 90 & $24,9 \pm 0,9$ & 45,4 & 0,636 & $-0,315$ \\
\hline 20 & 2Дз5Гз2Лпд1Ясз + Клг, Взг & 92 & $23,9 \pm 0,7$ & 34,0 & 1,089 & 1,874 \\
\hline 21 & 5Дз3Гз2Лпд & 96 & $26,2 \pm 1,3$ & 49,3 & 1,388 & 1,569 \\
\hline 22 & 9Дз1Гз + Лпд, Ясз & 89 & $25,1 \pm 1,0$ & 46,0 & 0,294 & $-0,994$ \\
\hline
\end{tabular}

Примітка. Позначення ті самі, що і в табл. 1. 
Підгінні деревні види позитивно впливають не тільки на ріст, але й на стан деревостанів. Їх присутність підвищує біотичну стійкість деревостанів, стимулює процеси очищення дерев від сучків та запобігає появі водяних пагонів на стовбурах дерев дуба. Результати дослідження санітарного стану дерев дуба звичайного наведено в табл. 3 .

Так, у $20 \%$ дослідних ділянок на деревах дуба немає водяних пагонів. В інших деревостанах кількість дерев дуба з водяними пагонами становить 5,3-53,3\% (див. табл. 3). Велику кількість дерев дуба з водяними пагонами $(36,9-53,3 \%)$ виявлено на ділянках 4, 12, 14, 15 і 22. Це різні за продуктивністю і породним складом деревостани. Так, на ділянках 4, 14, 15, 22 сформувались високоповнотні 3 найбільшим серед дослідних деревостанів запа- сом деревини, а на ділянці 12 - низькоповнотний чистий дубовий деревостан. Однозначного зв'язку появи і розвитку водяних пагонів на деревах дуба 3 часткою липи у складі деревостанів не встановлено. Очевидно, поява і формування водяних пагонів у дуба пов'язана з різними причинами. На пробних площах 12 і 22 сформувались чисті дубові, або 3 незначною часткою інших деревних видів деревостани. Під намет дубових деревостанів, зазвичай, проходить значна кількість світла, яка і стимулює появу водяних пагонів. У деревостані зі складом 5Дз2Лпд1Клг1Гз 1Взг+БпЧш (пр. пл. 14) такі деревні види, як липа, клен, граб, черешня відстають за висотою від дуба на 22-50\%, що не запобігає притіненню його стовбурів.

\section{Санітарний стан дуба звичайного в деревостанах 3 різною часткою} липи дрібнолистоїу їх складі

Таблиия 3

\begin{tabular}{|c|c|c|c|c|c|c|c|c|c|}
\hline \multirow{2}{*}{$\begin{array}{l}\text { № } \\
\text { пр. } \\
\text { пл. }\end{array}$} & \multirow{2}{*}{$\begin{array}{c}\text { Склад } \\
\text { деревостану }\end{array}$} & \multirow{2}{*}{$\begin{array}{l}\text { К-сть дерев } \\
\text { з вод. паг., \% }\end{array}$} & \multicolumn{6}{|c|}{$\begin{array}{c}\text { Кількість дерев за категоріями } \\
\text { санітарного стану, \% }\end{array}$} & \multirow{2}{*}{$\begin{array}{c}\text { Індекс } \\
\text { санітарного } \\
\text { стану }\end{array}$} \\
\hline & & & I & II & III & IV & $\mathrm{V}$ & VI & \\
\hline 3 & 6Лпд2Ясз1Дз1Бп + Гз, Взг, Клг & 0,0 & 55,6 & 17,8 & 13,3 & 11,1 & 0,0 & 2,2 & 1,89 \\
\hline 4 & 4Лпд2Ясз2Чш1Дз1Клг + Дч. Гз & 53,3 & 40,0 & 26,7 & 20,0 & 6,7 & 6,7 & 0,0 & 2,13 \\
\hline 5 & 4Дз3Клг2Лпд1Бп + Гз, Кля, Взг & 26,7 & 40,0 & 23,3 & 30,0 & 6,7 & 0,0 & 0,0 & 2,03 \\
\hline 6 & 5Лпд3Дз2Гз + Кля & 19,0 & 38,1 & 21,4 & 28,6 & 9,5 & 0,0 & 2,4 & 2,19 \\
\hline 7 & 4Лпд3Дз2Гз1Чш & 0,0 & 35,7 & 42,9 & 21,4 & 0,0 & 0,0 & 0,0 & 1,86 \\
\hline 8 & 5Дз4Лпд1Гз + Ясз, Клг, Чш & 27,0 & 37,0 & 23,0 & 24,0 & 14,0 & 0,0 & 2,0 & 2,23 \\
\hline 9 & 5Дз4Лпд1Гз & 20,5 & 25,6 & 35,9 & 20,5 & 17,9 & 0,0 & 0,0 & 2,31 \\
\hline 10 & 5Дз3Лпд1Кля1Гз + Ясз & 12,6 & 39,3 & 21,4 & 21,4 & 12,5 & 0,0 & 5,4 & 2,29 \\
\hline 11 & 3Дз4Гз2Лпд1Ясз + Клг, Чш & 26,7 & 26,7 & 26,7 & 20,0 & 26,7 & 0,0 & 0,0 & 2,47 \\
\hline 12 & 10Дз + Бп & 38,5 & 34,2 & 29,7 & 17,1 & 9,0 & 7,2 & 2,7 & 2,33 \\
\hline 13 & 9Дз1Ос + Лпд, Гз, Чш & 5,3 & 22,3 & 34,0 & 21,3 & 10,6 & 2,1 & 9,6 & 2,65 \\
\hline 14 & 5Дз2Лпд1Клг1Гз1Взг + Бп, Чш & 36,9 & 33,8 & 38,5 & 20,0 & 1,5 & 3,1 & 3,1 & 2,11 \\
\hline 15 & 6Дз3Лпд1Гз + Oc & 51,6 & 41,9 & 29,0 & 22,6 & 3,2 & 0,0 & 3,2 & 2,00 \\
\hline 16 & 9Дз1Гз + Лпд, Клг, Взг & 26,9 & 47,0 & 26,5 & 18,1 & 7,2 & 0,0 & 1,2 & 1,90 \\
\hline 17 & 6 бг2Лпд1Клг1Чш + Кля, Бкл, Взг & 17,6 & 47,6 & 31,3 & 13,5 & 4,1 & 0,0 & 4,1 & 1,91 \\
\hline 18 & 6Лпд2Дз2Гз & 0,0 & 63,6 & 36,4 & 0,0 & 0,0 & 0,0 & 0,0 & 1,36 \\
\hline 19 & 5Дз3Лпд2Гз + Клг & 27,1 & 56,3 & 18,8 & 16,7 & 4,2 & 0,0 & 4,2 & 1,85 \\
\hline 20 & 2Дз5Гз2Лпд1Ясз + Клг, Взг & 18,3 & 37,5 & 28,1 & 25,0 & 7,8 & 0,0 & 1,6 & 2,09 \\
\hline 21 & 5Дз3Гз2Лпд & 0,0 & 53,3 & 20,0 & 20,0 & 6,7 & 0,0 & 0,0 & 1,80 \\
\hline 22 & 9Дз1Гз + Лпд, Ясз & 49,3 & 39,1 & 33,3 & 20,3 & 4,3 & 0,0 & 2,9 & 2,01 \\
\hline
\end{tabular}

У деревостанах переважають дерева I (22,3$63,6 \%)$ i II $(17,8-42,9 \%)$ категорій санітарного стану. Сухі дерева трапляються на 70 \% дослідних ділянок в кількості 1,2-7,2\%. Індекс санітарного стану дуба змінюється в межах 1,36-2,65. Найкращим санітарним станом з індексом 1,36-1,91 характеризуються деревостани на ділянках 3, 7, 17, 18, 19, 21.
Зниження санітарного стану в середньовікових деревостанах на ділянках 9, 10, 11, 13 пов'язане зі значною їх густотою (1120-2507 екз./га) та посиленням процесів диференціації дерев унаслідок конкурентної взаємодії.

Висновки. В умовах свіжої грабової діброви Західного Поділля формуються дубові деревостани 3 
часткою липи дрібнолистої у їх складі від поодиноких дерев до 6-8 одиниць. Серед них переважають деревостани, в яких частка липи становить 2-4 одиниці. Дуб звичайний, незалежно від віку, росте за I $^{\mathrm{a}} \mathrm{I}^{\mathrm{b}}$ класами бонітету в деревостанах, де частка липи в їх складі змінюється в межах 2-8 одиниць і відстає в рості від дуба за висотою на 10,0-46,1\%. Кількість дерев липи в таких деревостанах становить 36-800 екз./га. Найгіршим ростом дуб звичайний характеризується на ділянках, де відмінності за показником середньої висоти дуба і липи є найменшими і становлять 0,4-6,8\%. На таких ділянках дуб досягає лише II класу бонітету. Кореляційний зв'язок між кількістю дерев липи в деревостанах і середньою висотою дуба виявився зворотним і помірним $(\mathrm{r}=-0,49)$.

Повнота і запас стовбурової деревини у досліджених лісостанах відзначаються високою варіабельністю навіть у межах вікових груп. У середньовікових деревостанах повнота становить $21,4-34,0 \mathrm{~m}^{2} /$ га, а запас деревини - 172-374 м³/га. У пристигаючих деревостанах ці показники становлять, відповідно, 24,6-34,9 м²/га і 263-409 м³/га, а в стиглих - 26,6-40,3 м²/га і 330-487 м³ га. Найбільшого запасу стовбурової деревини (409-487 м³/га) досягають деревостани, де частка липи у їх складі становить 3-6 одиниці.

Для досліджених деревостанів характерна правостороння форма кривої розподілу дерев за діаметром 3 переважанням помірного і сильного ступеня косості та незначним і помірним ступенями крутості. Водяні пагони у дерев дуба відсутні на $20 \%$ дослідних ділянок. В інших деревостанах різної повноти і продуктивності кількість дерев дуба з водяними пагонами становить 5,3-53,3\%. У деревостанах переважають дерева I і II категорій санітарного стану. Сухі дерева трапляються на $70 \%$ дослідних ділянок в кількості 1,2-7,2\%. Індекс санітарного стану дуба змінюється в межах 1,36-2,65.

\section{Бібліографічні посилання}

Gordienko, M. I. (1973). Interaction of pedunculate/ common oak and small-leaved lime. Scientific works of USHA. Forest science and protective afforestation, 94, 27-30 (in Russian).

Gordienko, M. I. \& Karpenko, I. V. (1996). Smallleaved lime and the lime-involving plantations. Kyiv: Agricultural education (in Ukrainian).

Gordienko, M. I. \& Gordienko, N. M. (2005). Forestry attributes of woody plants. Kyiv: Whistle (in Ukrainian).

Gorokhovskaya, V. S. (1950). The use of lime in shelterbelt planting and settlement gardening. MoscowLeningrad: Goslesbumisdat (in Russian).

Gensyruk, S. A., Shchevchenko, S. V., Bondar, V. S. et al. (1981). Integrated forest management zoning of Ukraine and Moldova. Kyiv: Scientific thought (in Russian).
Kharytonovych, F. N. (1968). Biology and ecology of tree species. Moscow: Forest industry (in Russian).

Lukanyuk, M. I. (2013). Pharmacognostic study of plants of the genus Tilia L.: Author's abstract. dis. for obtaining PhD in farm.sci.: speciality 15.00.02 Pharmaceutical chemistry and pharmacognosy». Kharkiv, 24 p. (in Ukrainian).

Murakhtanov, E. S. (1981). Lime species. Moscow: Forest industry (in Russian ).

Platonova, E. A., Lantratova, A. S. \& Golubin, K. Yu. (2006). Phytoceonotic role of small-leaved lime (Tilia cordata L.) in natural and urbanized areas [Electron resource] Hortus botanicus. Access mode to the resource: http: //* hortus.karelia.ru / bgm / hb.htm. (in Russian).

Polonchuk, N. S. (1965). Pure and mixed oak plantations in the conditions of fresh fertile oak forest type. Botanika, 7, 129-138. (in Russian)

Sanitary rules in the forests of Ukraine. (1995). Approved by the Resolution of the Cabinet of Ministers of Ukraine dated July 27, 1995, No. 555 (in Ukrainian).

Swynchuk, V. A. \& Soshensky, O. M. (2014). Peculiarities of the stem nontaperingness of small-leaved lime trees in the forest-steppe of Ukraine. Scientific Bulletin of NUBiP of Ukraine. Series of forestry and ornamental gardening, 198 (2), 65-70 (in Ukrainian).

SOU 02.02-37-476:2006 (2006). «Forest management trial plots. Method of establishment» (in Ukrainian).

Soshensky, O. M.; Girs, O. A., \& Swynchuk, V. A. (2015). Analysis of productivity of lime stands in Ukraine [Electronic resource]. Scientific reports of NUBiP of Ukraine, 3, 1-11. - Retrieved from: http:// nbuv.gov.ua/UJRN/Nd_2015_3_22 (in Ukrainian).

Soshensky, O. M. (2015). Size-quality structure of lime tree trunks in young- and middle-aged stands. Scientific Bulletin of NUBiP of Ukraine. - Series of forestry and ornamental gardening, 229, 31-38 (in Ukrainian).

Soshensky, O. M. (2015). Development of standards for determining the growing stock and size-quality structure of mature lime stands. Scientific Bulletin of $U N F U, 25.9,82-89$ (in Ukrainian).

Soshensky, O. M. (2016). Mensurational description of lime stand structure by diameter. Scientific Bulletin of UNFU, 26.3, 164-171 (in Ukrainian).

Yurkevych, I. D. (1960). Oak forests of the Belorussian SSR. Minsk: SA BSSR (in Russian). 


\section{Рост и формирование дубовых древостоев с участием липы мелколистой в условиях свежей грабовой дубравы Западного Подолья}

\section{В. К. Заика', Ю.С. Каленюк²}

Проведено исследование лесоводственно-таксационных показателей и санитарное состояние дубовых древостоев разного возраста с участием в их составе липы мелколистной. Контролем служили чистые и близкие к ним по составу дубовые и липовые древостои. Исследование проведено в средневозрастных, приспевающих и спелых древостоях.

Установлено, что в условиях свежих грабовых дубрав Западного Подолья формируются сложные дубовые древостои с участием ясеня обыкновенного, граба, липы мелколистной, ильма, кленов остролистого и явора и других древесных видов. Участие липы в их составе составляет от единичных деревьев до 6-8 единиц. Среди них преобладают древостои, в которых липа составляет 2-4 единицы. Дуб черешчатый растет по II-I ${ }^{\mathrm{b}}$ классам бонитета и достигает максимальной продуктивности $\left(\mathrm{I}^{\mathrm{a}}-\mathrm{I}^{\mathrm{b}}\right.$ бонитет) в древостоях, где участие липы в их составе преимущественно колеблется в пределах 2-8 единиц и при этом отставание ее в росте от дуба по высоте составляет 10-46\%. Наименьшей интенсивностью роста дуб характеризируется в древостоях, где отличия по высоте между дубом и липой составляют не более $7 \%$. Особенно неблагоприятные условия для роста дуба складываются в древостоях с преобладанием в росте липы над дубом. Корреляционная связь между количеством деревьев липы в древостоях и средней высотой дуба оказалась обратной и умеренной $(\mathrm{r}=-0,49)$.

Полнота и запас стволовой древесины древостоев сильно варьируют даже в пределах возрастных групп. В средневозрастных древостоях абсолютная полнота составляет 21,4-34,0 $\mathrm{m}^{2} /$ га, а запас древесины - 172-374 м³/га. В приспевающих насаждениях эти показатели, соответственно, составляют 24,6-34,9 м²/га и 263-409 м³/га, а в спелых $26,6-40,3 \mathrm{~m}^{2} /$ га и $330-487 \mathrm{~m}^{3} /$ га. Наибольший запас древесины (409-487 м³/га) сформировали древостои с участием липы в их составе от 3 до 6 единиц.

Для исследуемых насаждений характерна правосторонняя форма кривой распределения деревьев по диаметру с преобладанием умеренной и сильной

\footnotetext{
Заика Владимир Константинович - академик Лесной академии наук Украины, доктор биологических наук, профессор кафедры лесоводства. Национальный лесотехнический университет Украины, ул. генерала Чупринки, 103, г. Львов, 79057, Украина. Тел.: 032-239-27-85,+38-067-148-06-26. E-mail: vkzaika@ukr.net

Каленюк Юрий Степанович - преподаватель, Кременецкий лесотехнический колледж, ул. Молодежная 1 , с. Белокриница Тернопольской обл., 47014, Украина. Тел.: 035-46-52-404; +38096-367-15-16. E-mail: kaleniukyurii@gmail.com
}

степеней косости, а также незначительной и умеренной степенями крутости.

Исследование появления и развития водяных побегов на деревьях дуба показало, что на 20\% опытных участков их не обнаружено. В остальных насаждениях разной полноты и производительности количество деревьев дуба с водяными побегами составляет 5,3-53,3\%. Установлено, что в чистых дубовых и близким к ним по составу древостоях количество деревьев с водяными побегами значительно возрастает. В сложных насаждениях это наблюдается при условии значительного отставания на 22-50\% высоты сопутствующих древесных видов от высоты дубовой части лесного полога.

В насаждениях преобладают деревья дуба I и II категорий санитарного состояния. Сухие деревья встречаются на $70 \%$ исследуемых насаждений в количестве 1,2-7,2\%. Индекс санитарного состояния дуба колеблется в пределах 1,36-2,65. Снижение санитарного состояния в средневозрастных насаждениях связано со значительной их густотой (1120-2507 экз./га) и усилением процессов дифференциации деревьев вследствие конкурентного взаимодействия.

Ключевые слова: свежая грабовая дубрава; дубовые древостои; липа мелколистая; санитарное состояние; рост; формирование древостоев; лесоводственно-таксационные показатели; сопутствующие древесные виды; водяные побеги.

\section{Growth and formation of oak stands with small-leaved linden participation under fresh hornbeam oak forest site type conditions in the Western Podillya}

\author{
V. Zaika', Yu. Kalenuk ${ }^{2}$
}

In this paper we present the study of silvicultural and taxation indicators as well as the sanitary condition of oak stand of different ages with the participation of small-leaved linden, which grow under the conditions of fresh hornbeam in the Western Podillya. As a control we used clear and close to them in composition oak and linden stands. The study was conducted in middle-aged and mature stands.

We have established that in the fresh hornbeam of the West Podillya complex oak stands are formed with the participation of common ash, common hornbeam,

Volodymyr Zaika - full Member of the Forestry Academy of Sciences of Ukraine, Doctor of Biological Sciences, Professor of the Department of Forestry. Ukrainian National Forestry University. 103, General Chuprynka st., 103, Lviv, 79057, Ukraine. Tel.: 032235-30-12,+38-067-195-78-36. E-mail: vkzaika@ukr.net

Yurii Kalenuk - Lecturer, Kremenetskiy Forestry College, 1, Molodizhna st., Bilokrynytsya, Ternopil region, 47014, Ukraine. Tel: 03546-52-404; +38-096-367-15-16. E-mail: kaleniukyurii@ gmail.com 
small-leaf linden, Scots elm, maple and sycamore maple and other tree species. The share of linden in their composition is from single trees to 6-8 units. Among them stands are dominated, in which the linden is 2-4 units. Common oak grows according to II and $\mathrm{I}^{\mathrm{b}}$ bonitet and reaches maximum productivity ( $\mathrm{I}^{\mathrm{a}}$ and $\mathrm{I}^{\mathrm{b}}$ bonitet) in stands, where the proportion of linden in their composition mostly varies within 2-8 units and lags behind in growth from oak in height by 10.0$46,1 \%$. The worst growth of oak is characterized in stands, where the difference in height between oak and linden is not more than $7 \%$. The growth of the oak is especially suppressed by the prevalence of its height by the linden. The correlation between the number of linden trees in the stand and the average height of the oak turned out to be converse and moderate $(r=-0.49)$.

The completeness and stock of tree stem wood vary greatly even within the age groups. In the medium-aged stands, the absolute completeness is $21.4-34.0 \mathrm{~m}^{2} / \mathrm{ha}$, and the timber stock is $172-374 \mathrm{~m}^{3} / \mathrm{ha}$. In mature trees, these figures, respectively, are $24.6-34.9 \mathrm{~m}^{2} / \mathrm{ha}$ and $263-$ $409 \mathrm{~m}^{3} / \mathrm{ha}$, and in mature $-26.6-40.3 \mathrm{~m}^{2} / \mathrm{ha}$ and 330 $487 \mathrm{~m}^{3} / \mathrm{ha}$. The largest stock of wood $\left(409-487 \mathrm{~m}^{3} / \mathrm{ha}\right)$ is formed by a stand, where the proportion of linden in their composition is 3-6 units.

For experimental tree stands, the right-sided form of the distribution curve of trees in the tree stands in diameter is characterized by the predominance of moderate and high degree of sheath rate, and slight and moderate degrees of steepness.

In $20 \%$ of experimental areas of water shoots oak trees were not detected. In other trees of varying completeness and productivity the number of oak trees with water shoots is $5.3-53.3 \%$. It was established that the appearance of water shoots on oak trees grows in pure oak and close to them in the composition of tree stands. In complex tree stands, the appearance of water shoots on oak trees increases with a significant backlog of $22-50 \%$ of the height of the adjoining tree species from the height of the oak part of the forest tent.

In trees there are trees of the 1st and 2nd categories of sanitary condition. Deadwood trees are found in $70 \%$ of experimental sites in the amount of 1.2-7.2\%. The index of the sanitary state of the oak varies within 1.362.65. Worsening the sanitary state in middle age forests is associated with a significant density (1120-2507 per hectare) and with the processes of trees differentiation as a result of competitive interaction.

Key words: fresh hornbeam forest; oak stand; small-leaved linden; sanitary condition; growth; forest stand formation; forestry and taxation parameters; associated tree species; water shoots. 